\title{
WHEAT GRAIN ENRICHMENT WITH ZINC THROUGH USING ZINC FERTILISER AND PRECEDING PLANT RESIDUES INCORPORATION
}

\author{
ABOLFAZL BAGHBANI ARANI ${ }^{1 *}$, AMIN NAMDARI ${ }^{2}$, HOSSEIN NAZARLI ${ }^{2}$
}

\author{
${ }^{1}$ Payam Noor University, Tehran, Iran \\ ${ }^{2}$ Dry Land Agricultural Research Institute (DARI), Agricultural Research, Education and Extension \\ (AREEO), Iran
}

\begin{abstract}
ARANI, A.B. - MANDARI, A. - NAZARLI, H.: Wheat grain enrichment with zinc through using zinc fertiliser and preceding plant residues incorporation. Agriculture (Pol'nohospodárstvo), vol. 64, 2018, no. 2, pp. 80-86.
\end{abstract}

\begin{abstract}
Micronutrients and particularly zinc ( $\mathrm{Zn}$ ) deficiency affects crops productivity and human health, therefore improving $\mathrm{Zn}$ concentration within plant tissues might be regarded as an aim of sustainable agriculture. In this respect, a field experiment was carried out to examine the potential influence of preceding crop residues including bean and wheat incorporation into the soil as a way to improve zinc accumulation within subsequent wheat (Triticum aestivum L.) grain. The experiment was initiated at autumn 2014 and in the first year, a piece of farm land in Dehaghan-Isfahan-Iran was divided into two equal parts devoted to wheat and bean cultivation. At the end of the harvest season, aboveground plant residues were incorporated to 0-30 cm layer of soil. In the next year, the entire farm devoted to wheat production. The applied treatments included: control, zinc sulfate $(60 \mathrm{~kg} / \mathrm{ha}$ ), wheat residues, bean (Phaseolus vulgaris L.) residues, wheat residues + zinc sulfate and bean residue + zinc sulfate. The results of analysis of variance showed the highly significant differences between treatments in terms of grain zinc, protein, phytic acid to zinc molar ratio (PA/Zn), quantitative yield and soil electrical conductivity (EC). Soil pH and organic carbon (OC) were not affected by treatments while soil EC significantly increased by using plant residues. The highest grain yield $(3.8 \mathrm{t} / \mathrm{ha})$, grain protein $(10.3 \mathrm{mg} / \mathrm{kg})$ and zinc concentrations $(36 \mathrm{mg} / \mathrm{kg})$ were obtained by using bean residues plus $\mathrm{ZnSO}_{4}$ while the lowest quantities were related to control treatment. The treatments had no significant impact on grain acid phytic concentration but phytic acid / zinc molar ratio was affected by treatments and the lowest ratio (which is a positive attribute) was measured from plots containing bean residues plus $\mathrm{ZnSO}_{4}$ while the highest occurred in control plots.
\end{abstract}

Key words: biofortification, grain protein, micronutrients malnutrition, phytic acid, quantitative and qualitative yield, zinc sulfate

Micronutrients and especially zinc deficiency is rampant in soils under cereals cultivation throughout the world and it considerably reduces either quantitative or qualitative yield. The areas with $\mathrm{Zn}$-deficient soils are mainly areas where $\mathrm{Zn}$ deficiency in human is also rampant and particularly located in South and West Asia (Hotz \& Brown 2004; Alloway 2004). Zinc deficiency is particularly widespread in populations of developing countries where people's diet is cereal based as staple food (Cakmak 2008). Based on an estimation, micronutrient malnutrition, and especially zinc, iron deficit affects about three billion people around the world (Bouis 2007) and it has been estimated that over two billion people are at risk of $\mathrm{Zn}$ deficiency disorders (World Health Organization 2002; Hotz \& Brown 2004). However, it should also be mentioned that excessive zinc as a heavy metal has severe toxic effects on plants, animals, and human health (Ullah et al. 2015).

About 50 percent of cereals-growing lands around the globe encounter with different levels of zinc deficiency (Zhao \& McGrath 2009). Zinc

Abolfazl Baghbani Arani (*Corresponding author), Department of Agriculture Science, Payam Noor University, Tehran, Iran. E-mail: abolfazlbaghbani@yahoo.com

Amin Namdari, Hossein Nazarli, Dry land agricultural research institute (DARI), Agricultural Research, Education and Extension (AREEO), Iran 
deficiency in soils is caused by both primary and secondary deficiencies. In the case of primary deficiency, the total zinc concentration of the soil is limiting factor for plant requirements which mainly occurs in areas with sandy or strongly leached tropical soils (Cakmak et al. 2010). The range of total zinc concentrations in soils reported in the literature tends to show an overall mean total concentration of around $55 \mathrm{mg} \mathrm{Zn/kg} \mathrm{(Kiekens}$ 1995) however the zinc concentration in sandy soils of arid/semi-arid areas of South West Asia such as Iran (including the location of experiment) is considerably lower than global average (Table 1). Adequate zinc concentration in soil is a crucial factor to achieve high crop yields. In this respect, it is reported that in China, high wheat yields need $29.4 \mathrm{mg} \mathrm{Zn}$ per $\mathrm{kg}$ in shoots and $1.98 \mathrm{mg}$ DTPA-Zn/ $\mathrm{kg}$ in soil (Liu et al. 2017).

Soils affected by secondary zinc deficiency have enough zinc concentration to cover plant nutritional requirements yet the amount of zinc uptake is not enough to meet plant needs. High soil $\mathrm{pH}$ and high concentrations of calcium carbonate, bicarbonate, phosphate, calcium, magnesium and sodium in soils are the main factors which cause secondary zinc deficiency (Alloway 2009). Since agricultural soils in arid and semi-arid areas such as Iran are predominantly alkaline and taking into account crops needs, zinc and iron are considered as the most yield-limiting micronutrient in these areas.

Cereals and more precisely wheat and rice contain the main source of energy in developing countries especially South and West Asian countries (Cakmak 2008). Wheat grain generally has a low potential to accumulate $\mathrm{Zn}$ particularly when the content of $\mathrm{Zn}$ in soil is not sufficient. In addition, the amount of phytic acid which declines $\mathrm{Zn}$ availability in human body, is high within wheat grain. So, using agronomic approaches in order to enhance $\mathrm{Zn}$ accumulation within wheat grain is necessary. Biofortification means producing cereals which are enriched of micro nutrients and biofortified grains have higher bioavailability of these elements. Biofortification includes both agronomic and genetic approaches (Ghandilyan et al. 2006; Distelfeld et al. 2007). Producing cereals with enhanced content of micro-nutrients (biofortification) especially zinc through agronomic or genetic approaches and improving their bioavailability have been regarded as a cost-effective way to alleviate micro-nutrients malnutrition (Peleg et al. 2008).

Using organic materials like residues of preceding crop as agricultural inputs is a useful management strategy which on the one hand may improve soil structure and on the other hand provides minerals required by plants (Baldi \& Toselli 2014; HuesoGonzález et al. 2014). Local organic materials such as manure farmyard and plant residues are environment-friendly sources of micro-nutrients (Tejada \& Benítez 2014). Applying plant residues from pervious cultivation has been regarded as one of the agronomic biofortification approaches to enhance wheat grain quality (Khoshgoftarmanesh et al. 2017).

The current investigation was conducted in a region with a chronic $\mathrm{Zn}$ deficiency with the following goal: improving soil $\mathrm{Zn}$ bioavailability by employing agronomic approaches including using the plant residues of previous cultivation (bean and wheat) accompanied with chemical fertiliser $\left(\mathrm{ZnSO}_{4}\right)$. In this regard, the influence of mentioned inputs on quantitative and qualitative attributes of wheat grain where investigated.

\section{MATERIAL AND METHODS}

\section{Experimental, soil sampling and applied treatments}

The investigation was conducted as a field experiment in Dehaghan-Esfahan, Iran $\left(31^{\circ} 56^{\prime} \mathrm{N}\right.$, $\left.51^{\circ} 39^{\prime} \mathrm{E}\right)$. In the first year, a piece of farm land was divided into two equal parts, in one part, wheat was cultivated at November 2014 and another part was devoted to bean cultivation at early March 2015 . Each experimental plot area was $12 \mathrm{~m}^{2}(4 \mathrm{~m}$ in length, $3 \mathrm{~m}$ in width). The densities for wheat and bean were 250, 50 plants $/ \mathrm{m}^{2}$ respectively. After harvesting at summer, the harvested aboveground residues of both products were crushed into pieces of $1-3 \mathrm{~cm}$, then mixed, and incorporated into the $0-30$ $\mathrm{cm}$ layer of the farm soil. The chemical properties of each crop residues are presented in Table 2. In middle autumn 2015 (28 October), all experimental plots were devoted to bread wheat (Sepahan cultivar) cultivation. So the rotations during two years were bean-wheat and consecutive wheat cultiva- 
tion. The experiment was conducted as a randomized complete block design with three replications with six treatments, including using bean residues, wheat residues, zinc sulfate, wheat residues + zinc sulfate, bean residues + zinc sulfate and control (without plant residues of preceding crop and chemical fertiliser). The crops were irrigated to keep soil moisture at approximately $70 \%$ field capacity, using the basin irrigation method. Irrigation rates were based on evapotranspiration data collected at the local weather station of Dehaghan. During the experimental period, the medium temperature of day and night was 10 and $25^{\circ} \mathrm{C}$ and the relative humidity was about $35 \%$. During the growing period, the necessary agricultural cares like irrigation as plot and weeds control was done both mechanically and chemically (using 2,4-D). Finally, the wheat plants were harvested at June 2016.

The soil chemical and physical properties before performing experiment at autumn 2014 are presented in Table 1. The chemical zinc fertiliser for certain treatments was applied to soil in form of $\mathrm{ZnSO}_{4}$ at $60 \mathrm{~kg} / \mathrm{ha}$ based on what Iranian Soil and Water Institute had recommended (Milani et al. 1998). Soil properties including $\mathrm{pH}$, organic carbon and electrical conductivity were measured at the end of the experiment in summer 2016 to determine the influence of treatments.

Analysis of grain zinc, acid phytic (PA), PA/Zn molar ratio and protein concentration

In order to quantify the grain $\mathrm{Zn}$ content, in brief, samples were extracted by $\mathrm{HNO}_{3}$ and $\mathrm{H}_{2} \mathrm{O}_{2}$ in a microwave and the concentration of $\mathrm{Zn}$ within extracts measured by atomic absorption method microwave (Prasad 1999). To determine Phytic acid (PA) concentration in grains, the method of Makower (1970) was performed. In order to measure grain's protein concentration, first the concentration of nitrogen within grain was determined by using the well-known Kjeldahl method then to convert grain nitrogen to protein, based on what Tkachuk (1969) proposed, a specific factor (5.7) was used.

\section{Statistical analysis}

The data statistical analysis was done by SAS statistical software. To ensure residual normality, univariate procedure was used. The analysis of variance conducted through GLM procedure. The means comparison was also done by using $L S D$ test $(P \leq 0.05)$.

$\mathrm{T}$ a

Physical and chemical properties of soil $(0-30 \mathrm{~cm})$

\begin{tabular}{|l|c|c|c|c|c|c|c|c|c|c|}
\hline \multirow{2}{*}{ Soil texture } & $\mathrm{Mn}$ & $\mathrm{Zn}$ & $\mathrm{Fe}$ & $\mathrm{K}$ & $\mathrm{P}$ & $\mathrm{N}$ & Lime & Organic matter & \multirow{2}{*}{\begin{tabular}{c}
$\mathrm{EC}$ \\
\cline { 2 - 10 }
\end{tabular}} \\
\cline { 2 - 7 } Loam-clay & 8.5 & 0.3 & 4.8 & 235.2 & 9.1 & 1.51 & 35 & 1.1 & 7.4 & 1.1 \\
\hline
\end{tabular}

$\mathrm{T}$ a b 1 e 2

The properties of applied plant residues

\begin{tabular}{|c|c|c|c|c|c|c|c|c|c|c|c|}
\hline \multirow{2}{*}{ Plant residues } & \multirow{2}{*}{$\mathrm{C}: \mathrm{N}$} & \multirow{2}{*}{$\begin{array}{c}\text { Proteins } \\
{[\mathrm{g} / \mathrm{kg}]}\end{array}$} & $\mathrm{Cu}$ & $\mathrm{Mn}$ & $\mathrm{Zn}$ & $\mathrm{Fe}$ & $\mathrm{K}$ & $\mathrm{P}$ & $\mathrm{N}$ & \multirow{2}{*}{$\mathrm{pH}$} & \multirow{2}{*}{$\begin{array}{c}\mathrm{EC} \\
{[\mathrm{dS} / \mathrm{m}}\end{array}$} \\
\hline & & & \multicolumn{4}{|c|}{$[\mathrm{mg} / \mathrm{kg}]$} & \multicolumn{3}{|c|}{$[\%]$} & & \\
\hline Bean residual & 15.4 & 10.7 & 20 & 40 & 10 & 270 & 1.2 & 1.90 & 1.7 & 5.7 & 5.0 \\
\hline Wheat residual & 22.7 & 3.8 & 6 & 27 & 4 & 200 & 1.38 & 0.70 & 0.6 & 5.7 & 4.1 \\
\hline
\end{tabular}




\section{RESULTS AND DISCUSSION}

Response of soil EC, pH, organic carbon to applied treatments

The results of analysis of variance are summarized in Table 3. The means comparison showed that the highest soil EC was related to using wheat residues with or without chemical fertiliser while the lowest EC was observed in the treatment with $\mathrm{ZnSO}_{4}$ without residues (Table 4). On the opposite side with the current results, Nash and Baligay (1974) expressed that incorporating plant residues of preceding crop to soil by causing increase in biological activity and fungal, bacterial secretion, gradually reduces alkaline soil's $\mathrm{pH}$ while increases acidic soil's $\mathrm{pH}$. However the changes in soil $\mathrm{pH}$ caused by decaying residues are temporary and soil buffer property prevent marked changes in $\mathrm{pH}$. In current study, soil $\mathrm{pH}$ and organic carbon didn't respond to plant residues and $\mathrm{Zn}$ fertiliser. In fact, adding plant residues to soil increases organic matters yet the process is time consuming and the changes will occur during long

$\mathrm{T}$ a $\mathrm{b} 1$ e 3

Analysis of variance of soil properties, qualitative and quantitative yield in response to incorporating plant residues and $\mathrm{ZnSO}_{4}$ fertiliser

\begin{tabular}{|l|c|l|l|l|l|c|c|c|c|}
\hline $\begin{array}{l}\text { Source of } \\
\text { variation }\end{array}$ & df & $\mathrm{pH}$ & EC & O.C & $\begin{array}{c}\text { Grain } \\
\text { phytic } \\
\text { acid }\end{array}$ & $\begin{array}{c}\text { Phytic } \\
\text { acid } \\
\text { to zinc } \\
\text { molar } \\
\text { ratio }\end{array}$ & $\begin{array}{c}\text { Grain Zn } \\
\text { concentration }\end{array}$ & $\begin{array}{c}\text { Grain } \\
\text { protein }\end{array}$ & $\begin{array}{c}\text { Grain } \\
\text { yield }\end{array}$ \\
\hline Block & 2 & $0.005^{\mathrm{ns}}$ & $0.009^{\mathrm{ns}}$ & $0.001^{\mathrm{ns}}$ & $0.002^{\mathrm{ns}}$ & $11.04^{\mathrm{ns}}$ & $58.57^{\mathrm{ns}}$ & $0.38^{\mathrm{ns}}$ & $0.005^{\mathrm{ns}}$ \\
Treatment & 5 & $0.003^{\mathrm{ns}}$ & $0.023^{++}$ & $0.016^{\mathrm{ns}}$ & $0.032^{\mathrm{ns}}$ & $40.12^{++}$ & $78.57^{+}$ & $4.53^{++}$ & $0.488^{++}$ \\
Error & 10 & 0.010 & 0.002 & 0.010 & 0.019 & 4.00 & 25.94 & 0.24 & 0.010 \\
C.V [\%] & - & 1.31 & 9.89 & 6.13 & 20.13 & 9.62 & 16.24 & 5.49 & 3.11 \\
\hline
\end{tabular}

EC - electrical conductivity; O.C - organic carbon; ns - not significant at the 0.05 probability level

${ }^{+}$Significant at the 0.05 probability levels; ${ }^{++}$Significant at the 0.01 probability levels

$\mathrm{T}$ a b 1 e 4

Means comparison for soil properties, wheat qualitative and quantitative yield in response to incorporating plant residues and $\mathrm{ZnSO}_{4}$ fertiliser

\begin{tabular}{|c|c|c|c|c|c|c|c|c|}
\hline Treatment & $\mathrm{pH}$ & $\begin{array}{c}\mathrm{EC} \\
{[\mathrm{dS} / \mathrm{m}]}\end{array}$ & $\begin{array}{l}\text { O.C } \\
{[\%]}\end{array}$ & $\begin{array}{c}\text { Grain PA } \\
\text { [gr } 100 \mathrm{gr} / \\
\text { grain] }\end{array}$ & $\begin{array}{c}\text { Grain } \\
\mathrm{PA} / \mathrm{Zn} \\
{[\mathrm{mg} / 100 /} \\
\text { grain }]\end{array}$ & $\begin{array}{l}\text { Grain Zn } \\
{[\mathrm{mg} / \mathrm{kg}]}\end{array}$ & $\begin{array}{c}\text { Grain } \\
\text { protein } \\
{[\mathrm{mg} / \mathrm{kg}]}\end{array}$ & $\begin{array}{c}\text { Grain yield } \\
{[\mathrm{t} / \mathrm{ha}]}\end{array}$ \\
\hline Control & $7.33^{\mathrm{a}}$ & $0.83^{c}$ & $1.19^{\mathrm{b}}$ & $0.68^{\mathrm{a}}$ & $25.00^{\mathrm{a}}$ & $26.00^{\mathrm{d}}$ & $7.54^{c}$ & $2.80^{\mathrm{f}}$ \\
\hline $\mathrm{ZnSO}_{4}$ & $7.36^{\mathrm{a}}$ & $0.81^{\mathrm{c}}$ & $1.18^{\mathrm{b}}$ & $0.62^{\mathrm{ab}}$ & $19.00^{\mathrm{bc}}$ & $33.00^{\mathrm{ab}}$ & $7.92^{\mathrm{c}}$ & $3.10^{\mathrm{d}}$ \\
\hline Wheat residues & $7.26^{\mathrm{a}}$ & $0.99^{\mathrm{a}}$ & $1.72^{\mathrm{a}}$ & $0.70^{\mathrm{a}}$ & $24.60^{\mathrm{a}}$ & $28.00^{\mathrm{c}}$ & $8.20^{\mathrm{bc}}$ & $3.00^{\mathrm{e}}$ \\
\hline Bean residues & $7.22^{\mathrm{a}}$ & $0.92^{\mathrm{b}}$ & $1.64^{\mathrm{a}}$ & $0.6^{\mathrm{ab}}$ & $20.20^{\mathrm{b}}$ & $30.00^{\mathrm{b}}$ & $8.51^{\mathrm{bc}}$ & $3.40^{\mathrm{b}}$ \\
\hline $\begin{array}{l}\text { Wheat residues + } \\
\mathrm{ZnSO}_{4}\end{array}$ & $7.36^{\mathrm{a}}$ & $0.97^{\mathrm{a}}$ & $1.64^{\mathrm{a}}$ & $0.69^{\mathrm{a}}$ & $19.00^{\mathrm{bc}}$ & $35.00^{\mathrm{a}}$ & $9.91^{b}$ & $3.20^{\mathrm{c}}$ \\
\hline $\begin{array}{l}\text { Bean residues + } \\
\mathrm{ZnSO}_{4}\end{array}$ & $7.35^{\mathrm{a}}$ & $0.92^{\mathrm{b}}$ & $1.64^{\mathrm{a}}$ & $0.58^{b}$ & $16.00^{\mathrm{c}}$ & $36.00^{\mathrm{a}}$ & $10.30^{\mathrm{a}}$ & $3.80^{\mathrm{a}}$ \\
\hline
\end{tabular}

EC - electrical conductivity; O.C - organic carbon; PA - phytic acid

Similar letters within each columns show that the means are not significantly different based on $L S D$ test results at $P \leq 0.05$ 
term periods. As mentioned above, plant residues particularly of preceding wheat caused significant increase in soil EC. In this respect other researchers also reported that using organic compounds as input may increase soil EC since these compounds contain high amount of nutrients (Wanchez-Monedaro et al. 2001; Eghbal et al. 2004).

\section{Grain zinc concentration}

Using plant residues had significant effect on grain zinc concentration (Table 3 ). $\mathrm{ZnSO}_{4}$ had substantial impact on grain $\mathrm{Zn}$ concentration as the greatest quantities were obtained when this fertiliser was used either with plant residues (bean or wheat) or without them (Table 4). In absence of $\mathrm{ZnSO}_{4}$, bean residues caused significant improvement in grain $\mathrm{Zn}$ compared with wheat residues and control treatment (Table 4). It was already expressed that adding plant residues increases the organic carbon soluble in the soil which may absorb zinc element and improve $\mathrm{Zn}$ level within wheat grain (Schulin et al. 2008). Also, a significant correlation between soil zinc and zinc in grain has been reported although, in all the study treatments the grain zinc concentration was less than $35-40 \mathrm{mg} / \mathrm{kg}$ that is the critical level for grain quality (Cakmak 2008). Probably, not reaching to this critical level is caused by lack of primary soil zinc concentration. In fact, the most important factor regarding grain zinc concentration is the primary concentration of this element within soil (Calvino \& Sandra's 2003; Wissuma et al. 2007). Increasing Zn fertiliser (Zn$\mathrm{SO}_{4} \cdot 7 \mathrm{H}_{2} \mathrm{O}$ ) rate from 0 to $1,500 \mathrm{~kg} /$ ha markedly improves $\mathrm{Zn}$ content within wheat grain and contributes in zinc-biofortification (Wang et al. 2015). In this regard, promising results about the possibility of using $\mathrm{Zn}$ fertilisers in order to improve wheat grain $\mathrm{Zn}$ concentration has been achieved (Cakmak $2008)$. Since the potential of wheat new varieties to accumulate greater content of $\mathrm{Zn}$ within grain depends on the available $\mathrm{Zn}$ in the soil, breeding and agronomic biofortification strategies seem to be complementary (Joy et al. 2015). The effect of Zn fertilisation on grain $\mathrm{Zn}$ biofortification depends on soil $\mathrm{Zn}$ content. The soil in current study suffered from severe $\mathrm{Zn}$ deficiency and as a result grain $\mathrm{Zn}$ accumulation positively responded to $\mathrm{Zn}$ fertilisation. Soil $\mathrm{Zn}$ application is effective in terms of grain $\mathrm{Zn}$ biofortification provided $\mathrm{Zn}$ content in soil is lower than appropriate (Cakmak et al. 2010).

Grain phytic acid (PA) content and phytic acid to zinc $(P A / Z n)$ molar ratio

As shown in Table 3, the impact of treatments on grain acid phytic content was insignificant. In contrast, the differences between treatments in terms of phytic acid to zinc (PA/Zn) molar ratio (Table 3) were significant. Based on the result of means comparison, adding bean residues decreased the ratio and bean residues compared with wheat residues affected (reductive) the ratio more effectively. Furthermore, $\mathrm{ZnSO}_{4}$ fertiliser affected the ratio significantly as $\mathrm{PA} / \mathrm{Zn}$ ratio was lower in all treatments which included $\mathrm{ZnSO}_{4}$. This subject was also reported by researchers (Dorostcar et al. 2013). The $\mathrm{PA} / \mathrm{Zn}$ molar ratio is considered as an index of zinc bioavailability in human diet (Weaver \& Kannan 2002). In general, it is proposed that $\mathrm{Zn}$ absorption will be markedly limited when the PA/Zn molar ratio is over 15 (Gargari et al. 2007) and $\mathrm{Zn}$ bioavailability is considered as insufficient when the ratio is below 15 (Ryan et al. 2008). In this respect, Wang et al. (2015) reported that using high rates of $\mathrm{Zn}$ fertilisers to soil rapidly increases zinc concentrations while at the same time reduces PA concentrations in wheat grains and as a result the molar ratio of $\mathrm{PA} / \mathrm{Zn}$ declines.

\section{Grain protein concentration}

The results of analysis of variance in terms of grain protein are presented in Table 3. Using plant residues without chemical fertiliser and vice versa caused no significant improvement in grain protein (Table 4). When bean residues and zinc fertiliser applied together, it led to significant increase in grain protein as the greatest quantity was obtained by using bean residues and $\mathrm{ZnSO}_{4}$ (Table 4 ). There are other reports that express wheat rotation with other plants specially legumes, increases the wheat grain protein (Peck et al. 2008; Marschner 1995). Proteins are considered as a factor for improving zinc absorption in nutritive regimes. Greater content of grain protein improves element zinc absorption. Zinc consumption can be effective in curing the lack of zinc in human, increasing the protein and the zinc concentration in grain (Marschner 1995). 
Grain yield

Bean residues incorporation into the soil, increased the grain yield by 18 percent compared to control (Table 4). The highest grain yield was obtained when the bean residues with zinc sulfate were added to the soil together and it led to 26 percent increase in grain yield compared to control. As shown in Table 2, the bean residues contained higher content of zinc and protein. So the greater grain yield by using bean residues might be caused of more nitrogen and zinc in bean residues. It is reported that using $23 \mathrm{~kg}$ of zinc fertiliser can increase wheat grain yield significantly (Cakmak 2008). The promoting impact of preceding legumes on following cereal's growth, may be caused by the nutrients release during decomposition of legume residues (Theuerl \& Buscot 2010) that consequently are utilized by cereal crop. In addition to well-known ability of legumes regarding nitrogen biological fixation, these crops also may mobilize $\mathrm{P}$ in soils and thereby often contain greater amount of $\mathrm{P}$ within plant organs. This source of $\mathrm{P}$ subsequently will become available during decomposition of residues (Nuruzzaman et al. 2005).

\section{CONCLUSIONS}

This experiment showed that the using plant residues particularly legume species (in this case bean) might be a useful way to improve wheat quantitative and qualitative yield through grain enrichment of zinc and protein. Furthermore, since soil suffered from severe zinc deficiency, applying $60 \mathrm{~kg} / \mathrm{ha}$ of $\mathrm{Zn}$ chemical fertiliser $\left(\mathrm{ZnSO}_{4}\right)$ accompanied with plant residues caused significant improvement in grain $\mathrm{PA} / \mathrm{Zn}$ ratio (lower is better), grain $\mathrm{Zn}$ and grain yield. Also, the results of the experiment showed that residues with lower $\mathrm{C} / \mathrm{N}$ ratio such as bean may have a more effective role in growth and yield of succeeding wheat. Using plant residues with high degradation might be more useful for crops with low growth period. In addition since using plant residues caused increase in soil EC, the amount of residues must be applied precisely to prevent soil salinization. At the end, it must be mentioned that in current investigation the data were gathered only for one year so the obtained results are preliminary.

\section{REFERENCES}

ALLOWAY, B.J. 2004. Zinc in soils and crop nutrition. In International Zinc Association, IZA Publications, pp. $1-116$.

ALLOWAY, B.J. 2009. Soil factors associated with zinc deficiency in crops and humans. In Environmental Geochemistry and Health, vol. 31, pp. 537-548. DOI: doi. org/10.1007/s10653-009-9255-4

BALDI, E. - TOSELLI, M. 2014. Mineralization dynamics of different commercial organic fertilisers from agro-industry organic waste recycling: an incubation experiment. In Plant Soil Environment, vol. 60, pp. 93-99.

BOUIS, H.E. 2007. The potential of genetically modified food crops to improve human nutrition in developing countries. In The Journal of Development Studies, vol. 43, pp. 79-96. DOI: doi.org/10.1080/00220380601055585

CAKMAK, I. - PFEIFFER, W.H. - MCCIAFFERTY, B. 2010. Biofortification of durum wheat with zinc and iron. In Cereal Chemistry, vol. 87, pp. 10-20. DOI: 10.1094/ CCHEM-87-1-0010

CAKMAK, I. 2008. Enrichment of cereal grains with zinc: Agronomic or genetic bio fortification. In Plant and Soil, vol. 302, pp. 1-17. DOI: doi.org/10.1007/s11104-0079466-3

CALVINO, P.A. - SANDRA'S, V.O. 2003. Quantification of environmental management effect on the yield of late sown soybean. In Field Crop Research, vol. 83, pp. 6777. DOI: $10.1016 / \mathrm{S} 0378-4290(03) 00062-5$

DISTELFELD, A. - CAKMAK, I. - PELEG, Z. - OZTURK, L. - YAZICI, A.M. - BUDAK, H. - SARANGA, Y. - FAHIMA, T. 2007. Multiple QTL-effects of wheat Gpc-B1 locus on grain protein and micronutrient concentrations. In Physiologia Plantarum, vol. 129, pp. 635-643. DOI: 10.1111/j.1399-3054.2006.00841.x

DOROSTCAR, V. - AFYOUNI, M. - KHOSHGOFTARMANESH, A.H. 2013. Effect of some plant debris before planting on concentrations of total and absorbable zinc and phytic acid content of wheat grain. In Journal of Sciences and Technology of Agriculture and Natural Resources, vol. 17, pp. 81-93.

EGHBAL, B. - GIINTING, D. - GILLEY, J. 2004. Residual effects of manure and compost application on com production and soil properties. In Agronomy Journal, vol. 96, pp. 442-447.

GARGARI, B.P. - MAHBOOB, S. - RAZAVIEH, S.V. 2007. Content of phytic acid and its mole ratio to zinc in flour and breads consumed in Tabriz Iran. In Food Chemistry, vol. 100 , no. 3, pp. 1115-1119. DOI: doi.org/10.1016/j. foodchem.2005.11.018

GHANDILYAN, A. - VREUGDENHIL, D. - AARTS, M.G.M. 2006. Progress in the genetic understanding of plant iron and zinc. In Physiologia Plantarum, vol. 126, pp. 407-417. DOI: 10.1111/j.1399-3054.2006.00646.x

HOTZ, C. - BROWN, K.H. 2004. Assessment of the risk of zinc deficiency in populations and options for its control. In Food Nutrient Bulletin, vol. 25, pp. 94-204. DOI: $10.1177 / 15648265040251$ S201

HUESO-GONZALES, P. - MARTINEZ-MURILLO, J.F. - RUIZ-SINOGA, J.D. 2014. The impact of organic amendments on forest soil properties under Mediterranean climatic conditions. In Land Degradation and development, vol. 25, pp. 604-612. DOI: 10.1002/ldr.2296

JOY, E.J.M. - ANDER, E.L. - YOUNG, S.D. 2014. Dietary mineral supplies in Africa. In Physiologia Plantarum, vol. 151 , no. 3 , pp. $208-229$. DOI: $10.1111 /$ ppl.12144 
KHOSHGOFTARMANESH, A.H. - NORUZI, M AFYUNI, M. - SCHULIN, R. 2017. Zinc biofortification of wheat through preceding crop residue incorporation into the soil. In European Journal of Agronomy, vol. 89, pp. 131-139. DOI: doi.org/10.1016/j.eja.2017.05.006

KIEKENS, L. 1995. Zinc. In ALLOWAY, B.J. (ed.) Heavy Metals in Soils ( $2^{\text {nd }}$ edn.). London : Blackie Academic and Professional, pp 284-305.

LIU, D. - ZHANG, W. - PANG, L. - ZHANG, Y. - WANG, X. - LIU, Y. - CHEN, X. - ZHANG, F. - ZOU, C. 2017 Effects of zinc application rate and zinc distribution relative to root distribution on grain yield and grain $\mathrm{Zn}$ concentration in wheat. In Plant and Soil, vol. 411, pp. 167-178. DOI: doi.org/10.1007/s1110

MAKOWER, R.U. 1970. Extraction and determination of phytic acid in beans. In Cereal Chemistry, vol. 47, pp. 288-291.

MARSCHNER, H. 1995. Mineral nutrition of higher plants. Second Edition Academic Press. New York, 890 pp.

MILANI, P.M. - MALAKOUTI, M.J. - KHADEMI, Z. BALALI, M.R. - MASHAYEKHI, M. 1998. A Fertilizer Recommendation Model for the Wheat Field of Iran. Soil and Water Research Institute, Tehran, Iran.

NASH, V.E. - BALIGAY, V.C. 1974. The growth of soybean roots in relation to soil micro morphology. In Plant and Soil, vol. 41, pp. 81-89. DOI: doi.org/10.1007/ BF00017946

NURUZZAMAN, M. - LAMBERS, H. - BOLAND, M.D.A - VENEKLAAS, E.J. 2005. Phosphorus uptake by grain legumes and subsequently grown wheat at different levels of residual phosphorus fertiliser. In Australian Journal Agriculture Research, vol. 56, pp. 1041-1047. DOI: 10.1071/AR05060.

PECK, A.W. - MCDONALD, G.K. - GRAHAM, R.D. 2008. Zinc nutrition influences the protein composition of flour in bread wheat (Triticum aestivum L.). In Journal Cereal Science, vol. 47, pp. 266-274. DOI: doi.org/10.1016/j. jcs.2007.04.006

PELEG,Z.-SARANGA, Y.-YAZICI,A.-FAHIMA, T.-OZTURK, L.-CAKMAK, I. 2008. Grain zinc, iron and protein concentrations and zinc-efficiency in wild emmer wheat under contrasting irrigation regimes. In Plant and Soil, vol, 306, pp. 57-67. DOI: doi.org/10.1007/s11104-0079417-Z

PRASAD, B. 1999. Conjoint use of fertilisers with organics, crop residues and green manuring for their efficient use in sustainable crop production. In Fertilizer Research, vol. 44, pp. 67-73.

RYAN, M.H. - MCINERNEY, J.K. - RECORD, I.R. -ANGUS, J.F. 2008. Zinc bioavailability in wheat grain in relation to phosphorus fertilizer, crop sequence and mycorrhizal fungi. In Journal of the Science of Food and Agriculture, vol. 88, pp. 1208-1216. DOI: 10.1002/jsfa.3200
SCHULIN, R. - KHOSHGOFTARMANESH, A.H. AFYUNI, M. - NOWACK, B. - TEJADA, M. - BENITEZ, C. 2014. Effects of crushed maize straw residues on soil biological properties and soil restoration. In Land Degradation and Development, vol. 25, pp. 501-509. DOI: $10.1002 / 1 \mathrm{dr} .2316$

THEUERL, S. - BUSCOT, F. 2010. Laccases: toward disentangling their diversity and functions in relation to soil organic matter cycling. In Biology and Fertility of Soils, vol. 46, pp. 215-225. DOI: doi.org/10.1007/s00374-010$0440-5$

TKACHUK, R. 1969. Nitrogen-to-protein conversion factors for cereals and oilseed meals. In Cereal Chemistry, vol. 46 , pp. 419-423.

WANCHEZ-MONEDARO, M.A. - ROIG, A. - PAREDES, C. - BERNAL, M.P. 2001. Nitrogen transformation during organic waste composting by the rutgers system and its effects on $\mathrm{pH}, \mathrm{EC}$ and maturity of composting mixtures. In Bioresource Technology, vol. 78, pp. 301308. DOI: doi.org/10.1016/S0960-8524(01)00031-1

WANG, Z. - LIU, Q. - PAN, F. - YUAN, L. - YIN, X. 2015. Effects of increasing rates of zinc fertilisation on phytic acid and phytic acid/zinc molar ratio in zinc bio-fortified wheat. In Field Crops Research, vol. 184, pp. 58-64. DOI: doi.org/10.1016/j.fcr.2015.09.007

WEAVER, C.M. - KANNAN, S. 2002. Phytate and mineral bioavailability. In REDDY, N.R. - SATHER, S.K. (Eds.) Food Phytate. Boca Raton : CRC Press, pp. 211-223.

WISSUMA, M. - ISMAIL, A.M. - GRAHAM, R.D. 2007. Rice grain zinc concentrations as affected by genotype, Native soil-zinc availability, and zinc fertilisation. In Plant and Soil, vol. 306, pp. 37-48. DOI: doi. org/10.1007/s11104-007-9368-4

WORLD HEALTH ORGANIZATION. 2002. The world health report. Reducing risks, promoting healthy lives. Geneva : World Health Organization. 236 pp. ISBN 92 41562072

ULLAH, A. - HENG, S. - FAROOQ, M. - MUNIS, H. FAHAD, S. - YANG, X. 2015. Phytoremediation of heavy metals assisted by plant growth promoting (PGP) bacteria: A review. In Environmental and Experimental Botany, vol. 117, pp. 28-40. DOI: doi.org/10.1016/j.envexpbot.2015.05.001

ZHAO, F.J. - MCGRATH, S.P. 2009. Biofortification and phytoremediation. In Current Opinion in Plant Biology, vol. 12, pp. 373-38. DOI: doi.org/10.1016/j. pbi.2009.04.005

Received: January 13, 2018 